\title{
IMPLEMENTATION OF COOPERATIVE TEACHING METHODS TO INCREASE OF TEACHING THE UNDERSTANDING OF BASIC ELECTRONICS SUBJECS IN ELECTRICAL DEPARTMENT SMK NEGERI 1 PARIAMAN PADANG
}

\author{
Aswardi \\ Electrical Department, Engeenering Faculty, \\ Padang State University-Kampus Air Tawar, \\ Padang 25131, Indonesia \\ aswardi@ft.unp.ac.id
}

This research is motivated from the learning outcomes of the students at SMK Negeri 1 Pariaman class X TITL on subjects Understanding the Basics Electronics (MDE) which is still not optimal. One of the factors that influence student learning outcomes is the low learning process centered on the teacher (teacher center), so it can not raise the activeness of students in learning. Therefore, it's really need a method of cooperative learning"Think Pair Share" that can encourage students to be more active and creative in the learning process. Students will discuss with friends his chairmate, and mastery the subject matter togother. Moreover, using this method the student is able to solve the problems experienced during the learning process well. The goal of this study is to see significantly the differences of student learning outcomes in subjects MDE using the Think Pair Share and lecture in SMK Negeri 1 Pariaman.

This research is a Quasi Experiment with design "Posttest Only Control Design". The subjects were students of class X SMK N 1 Pariaman enrolled in the academic year 2015/2016 which consists of two classes, namely X TITL-1 and TITL-2. From these two classes were randomly selected, class X TITL-1 As the experimental and class X TITL-2 as the control class. To see the beginning of the student's ability to analyze daily tests (UH) on the subjects of MDE. Collecting data in this study using achievement test (posstest) in the from of an objective matter as much as 25 items. Data were analyzed using two different test average ( $t$-test).

Based on the research results obtained average value 82.85 post test experimental class and control class 74.91. These results indicate that there are significant of student learning outcomes between experimental class using "Think Pair Share" cooperative methods compared with control classes using traditional method.

Keywords : Method Think Pair Share, Methods of Teaching and Learning Outcomes. 


\section{Introduction}

Education is an attempt to create human resources that have the knowledge that is useful to make man more qualified and immoral. Vocational High School (SMK) is an educational institution not only provides knowledge but also provide students with skills. Schools are an effective tool in supporting the development and enhancement of the human family resources towards a more positive direction. One of the subjects that the productive part is very important that given to students in the field of Teknik Instalasi Tenaga Listrik (TITL) is Memahami Dasar-dasar Elektronika (MDE). This course covers the activities to educate, train and prepare students to be able to master the basic concepts of electronics in the field of electricity

Based on the results of preliminary observations that the author did in SMK Negeri 1 Pariaman in learning MDE. Seen many students are bored, sleepy, inattentive, and inaction on the material being taught teachers. By the time the teacher explains the subject matter and gives examples of questions, a lot of students who have not been creative and active and less dare to issue its opinion in the learning process. Low interest and activity of students in the classroom lead to lower learning outcomes achieved by students.

Referring to the results of interviews with subject teachers MDE for observation, obtained information that student learning is less eager to follow the lessons, often out of the classroom and unplug. After the evaluation was still a lot of students who do not understand the subject matter. As a result of student learning outcomes have not reached the Kriteria Ketuntasan Minimum (KKM).

Many factors affect student learning outcomes as internal factors and external factors. Among the external factors one of which is a method of learning which is one component that could affect the study results. How much influence teaching methods to student learning outcomes can be determined by which method is better to achieve the learning outcomes. Anticipating the low student learning, should the effort to develop creativity in the learning process management strategies. Management strategy in question is the student not just serve as the object alone but also as a subject of direct actors in the learning process.

One of the methods that can be used is a method to study groups (cooperative), because in group learning can foster students' awareness and sense of responsibility in students. One method of cooperative suspected suitable to be applied is the method of 
learning Think Pair Share. Cooperative learning methods TPS type is cooperative learning methods that have defined eksplinsit procedure gives more time for students to think deeply about what is being described or experienced (thinking, respond to, and help each other). They help students in developing and associate facts and concepts that had been learned in problem solving.

This method could encourage students to be more active and creative in the learning process and will encourage learning in the classroom more leverage because of the methods they have to explain to his friend the material being studied. This method is suitable for subjects that form of understanding the material as subjects MDE containing about recognition, understanding and penerapaan of electronic components for the methods of TPS students clarify each other, in this way it is expected that students will more quickly understand, because his direct explained.

According Fathurrohman (2015: 86), TPS is a type of cooperative learning that has procedures set out explicitly to give students plenty of time to think, to answer and help each other. Furthermore, according to Trianto (2011: 61), Method cooperative TPS is an effective way to diversify the atmosphere of a class discussion on the assumption that all is resistant or discussion needs settings for mengendaliakan class as a whole and the procedures used in the method of cooperative TPS can give students more time to think, to respond and help each other.

Advantages of TPS method, according Istarani (2012: 68) namely; (1) increase the power of reason, critical power and imagination of the students to the problems, (2) increased cooperation between the students as they work in groups, (3) improve the ability of students to understand and respect the opinions of others, (4) enhance students' skills in presenting opinion as implementation science, and (5) the teacher is more likely to add a child's knowledge when it finished discussions.

Based on the problems described above, it can be formulated problems in this paper, namely, how the application of methods of cooperative learning TPS MDE in SMK N 1 Pariaman. Furthermore, this study aims to find a significant difference in student learning outcomes in learning MDE using the type cooperative TPS and traditional methods at SMK Negeri 1 Pariaman

\section{Research Methods}

This type of research that will be done is quasi (quasi-experimental), to determine differences in learning outcomes of students in learning MDE using 
cooperative learning TPS and traditional methods in vocational Negeri 1 Pariaman. The subjects were students of class X TITL electricity power engineering expertise SMK Negeri 1 Pariaman registered in the first semester of the 2015/2016 academic year with the number of 71 people consisting of TITL-1 amounted to as many as 35 students, and TITL-2 is about 36 students. according to the type of research conducted, it is necessary to sample two classes, namely the experimental class and the control class. Selection of experimental class and control class is done by analyzing the average value of daily tests of students. After the second class can be used as a research object, the determination of the experimental class and control class can be determined by simple random sampling technique.

The instrument used in this study is in the form of 30 questions about the objective. Before the test questions about the tests used to determine the validity, reliability, level of difficulty and different power about the matter. Tests performed on the class X SMK N Dhuafa Padang.

Validity is based on calculations where if $r_{\text {count }}>r_{\text {table }}$ the test items are considered valid and if $r_{\text {count }}<r_{\text {table }}$ the test items to be invalid and disqualified hence the amount of matter that is otherwise valid and can be used for After the validity of the question test instrument research consists of 30 questions, was obtained 5 questions which were not valid and another item 25 is valid. Based on the calculation of reliability, the reliability values obtained about the test of 0.83 . Then the arithmetic result is 0.83 consulted with tables scale level of reliability problems, so it can be known about these tests are included in a very high level of reliability.

\section{Results and Discussion}

\section{Description of Data}

Description of the data from this study is in the form of student learning outcomes data experimental class and control class. Learning outcomes data as a value for each of the students in the experimental class numbering 35 people and control classes totaling 36 people. Value of students in the experimental class ranges between 64-92, while in the control group ranged from 60-88.

For more details, a histogram of the frequency distribution illustrated in Figure 1 and 2:

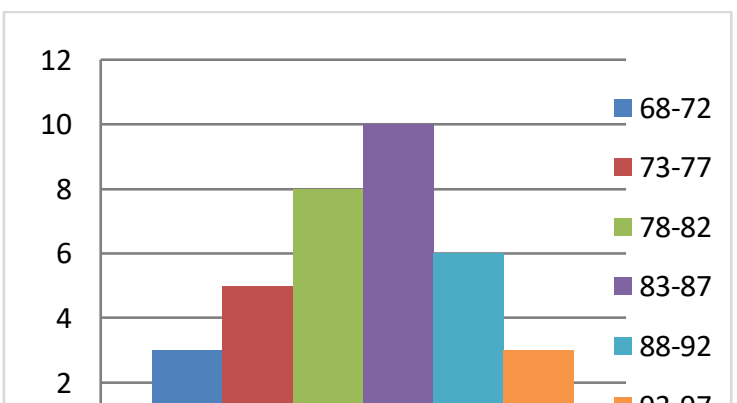


Figure 1. Histogram of frequency distribution experimental class

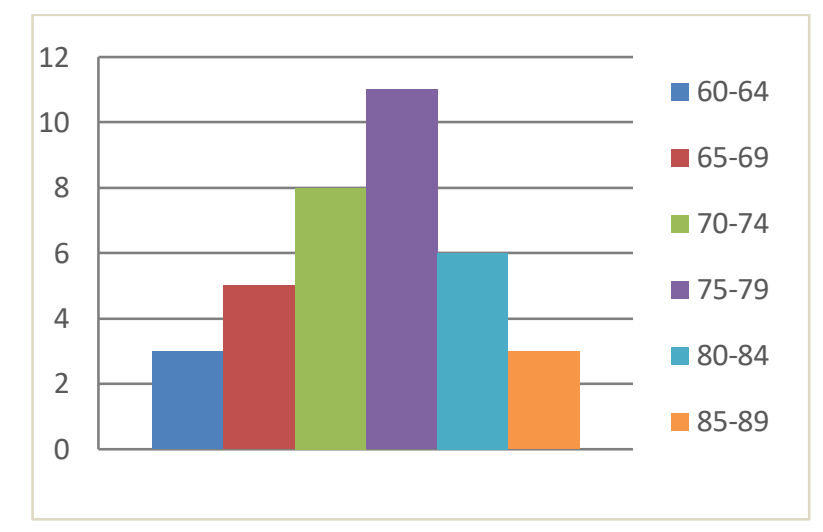

Figure 2. Histogram of frequency distribution control class

\section{Test of Requirements Analysis}

a. Normality Test

To ascertain whether the data of the subject class research normally distributed, then tested for normality using the Chi squared. Based on data analysis for experimental class $\chi^{2}$ count $=1.40$ and $\chi^{2}$ count for the control class $=1,83$. For the value of the subject class $\chi^{2}$ table at significant level at $\alpha=0.05$ and degrees of freedom $(\mathrm{df})=6-1=5$, then the value obtained $\chi^{2}$ table in the experimental class and control 11.07 thus the $\chi^{2}$ count $<\chi^{2}$ table, this means that the data obtained from the second class, or research subjects for an experimental class $1.40<11.07$ and for control class $1.83<11.07$ can be concluded that the learning outcomes in subjects MDE with normal distribution.

\section{b. Test Homogeneity}


The results of calculations for homogeneity test with the largest variance than the smallest variance obtained $F_{\text {count }}=1.01$ then from $F$ count compared with $\mathrm{F}_{\text {table, }}$ where $\mathrm{F}_{\text {table }}$ with $\alpha=0.05$ with the numerator $\mathrm{df}=\mathrm{n}-1$ $=35-1=34$ and $\mathrm{dk}$ denominator $=\mathrm{n}-1=36-1=35$, then searched in table $\mathrm{F}$ obtained $\mathrm{F}_{\text {table }}=1.01$. Conclusions used the test criteria if $\mathrm{F}$ count $\geq \mathrm{F}$ table means not homogeneous, and if $F_{\text {count }} \leq F_{\text {table }}$ means homogeneous. So from the calculations, the $F_{\text {count }} \leq F_{\text {table }}$ or $1.01<1.80$. It can be concluded that the samples have a homogeneous variance. Having carried out tests of normality and homogeneity tests and obtained data result of learning MDE is normally distributed and both samples have a homogeneous variance.

\section{Hypothesis Testing}

The results of the hypothesis test calculations obtained $t_{\text {count }}$ of 4.13 . Then $\mathrm{t}_{\text {count }}$ compared with $\mathrm{t}_{\text {table }}$ with $\alpha=0.05$ degrees of freedom $(\mathrm{df})=\mathrm{n} 1+\mathrm{n} 2$ $-2=35+36-2=69$, searched in the table values obtained $t$ distribution table $=1,996$. Conclusions criteria for testing the hypothesis that if $t_{\text {count }}>t_{\text {table }}$ (4.13> 1.997), then the null hypothesis is rejected or accepted working hypothesis Ha. and there are significant differences in student learning outcomes using TPS type of cooperative learning methods with traditional methods in the subjects Understanding the Basics of Electronics at SMK Negeri 1 Pariaman.

\section{Discussion}

Based on the test results of students' average grade obtained experimentally (X TITL 1) ie 82.85 which passed the 27 students who previously only 10 students and a higher than average number of control class (X TITL 2) ie 74.91 which graduated 20 students from the previous 12 students. This shows that the type cooperative learning methods TPS can improve student learning outcomes in subjects in class X MDE TITL 1 SMK Negeri 1 Pariaman.

The results of the data analysis has been done that $t_{\text {count }}$ of 4.13 compared

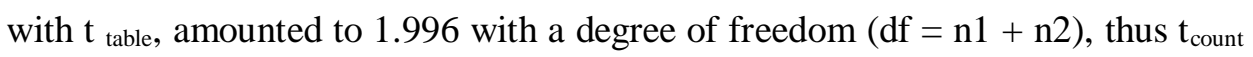
is greater than $t_{\text {table }}$ which means that there are significant differences in the level of 0,05 to the learning outcomes of students using cooperative learning methods SMT type with traditional methods. The results of the analysis to test the 
hypothesis $\mathrm{t}=4.13$ and table $=1.996$, it also indicates the use of learning methods TPS in improving student learning outcomes in subjects in class X MDE SMK Negeri 1 Pariaman, influential in improving student learning outcomes and can be accepted as methods of learning on the subjects of MDE.

Selection of the method according to the characteristics of a subject can enhance the creativity of the students in understanding the subject matter, so that student learning outcomes in the classroom learning meningkat.Proses experiments provide questions to the students and the students to think about questions, divided into two according to the seat or in pairs, then exchanging ideas in solving the matter and discuss it. If the discussion has been completed, the teacher randomly select a partner to look forward class and explain the extent of his understanding.

The learning method is considered suitable for the material that is understanding of subjects such as MDE, so students who are less intelligent will be helped by his friend in an attempt to understand the material. This is in accordance with the opinion of Trianto (2011: 61) states that the type cooperative learning TPS is designed to influence students' interaction patterns.

Furthermore Fathurrohman (2015: 86) states that the TPS method has procedures set out explicitly to give students plenty of time to think, to answer and help each other. This learning comes from the concept that students can easily find and understand the material which is difficult if they were in discussions with his friend. The average value of post test control class appears to be lower than the experimental class, for the use of methods that are less precise. The traditional method is more suitable in the subjects of a procedural nature and this method is centered on the teacher, so the teacher must be smart in classroom management. If teachers are not able to manage a class, then the learning process will not work effectively. This was confirmed by the results of research Adrizal (2012) which concluded that the learning outcomes of students using cooperative learning TPS higher than traditional method.

\section{Conclusions and recommendations}

Based on research that has been done, it can be concluded that there are significant differences between the results of student learning using cooperative methods SMT type with traditional methods in the subjects MDE at SMK Negeri 1 Pariaman as indicated by the average student learning outcomes experimental class 
is 82.85 , while for the average student learning outcomes that control class 74.91 . Referring to the results of research it is suggested, the teachers of the subjects MDE TITL class X SMK Negeri 1 Pariaman to be able to use methods of cooperative TPS so that students can be motivated and actively involved in the learning process. Furthermore, for learning using cooperative learning effective TPS type, to do training on the teaching methods of the school to the teachers of subjects. Using cooperative learning TPS can be used as an alternative for teachers of SMK Negeri 1 Priaman to increase the activity of individuals in the group and student learning outcomes in subjects MDE

\section{References}

Adrizal, 2013.'Perbedaan Hasil Belajar Siswa Dengan Penerapan Pembelajaran Kooperatif Tipe Think Pair Share Yang Di Lengkapi Modul Berwarna Pada Mata Pelajaran Rangkaian Listrik Di SMKN 1 Bukittinggi”. Skripsi. Padang : UNP.

Depdiknas. 2008. Pengembangan Perangkat Penilaian Psikomotor. Jakarta: Gramedia. 2009. Asesmen. Jakarta: Cendikia Insani.

Dimyati, dkk. 2006. Belajar Dan Proses Pembelajaran. Jakarta: PT. Remaja Rosyda Karya.

Djaafar, Tengku Zahara. 2001. Konstribusi Strategi Pembelajaran Terhadap Hasil Belajar. Padang: Fakultas Ilmu Pendidikan Universitas Negeri Padang.

Djamarah, Syaiful Bahri. 2000. Guru dan Anak Didik dalam Interaksi Edukatif, Jakarta: PT. Rineka Cipta. . 2006. Strategi Belajar Mengajar. Jakarta: PT. Rineka Cipta.

Fathurrohman, Muhammad. 2015. Model-Model Pembelajaran Inovatif. Jogjakarta: Ar-Ruzz Media.

Hamalik, Oemar. 2008. Proses Belajar Mengajar. Jakarta: Bumi Aksara.

Istarani.2012.58 Model PembelajaranInovatif. Medan: Media Persada.

Purwanto, Ngalim. 2004. Psikologi Pendidikan. Jakarta: PT. Remaja Rosyda Karya.

Riduwan. 2006. Belajar Mudah Penelitian Untuk Guru, Karyawan dan Peneliti Pemula.

Bandung: Alfabeta. 
Sagala, Syaiful. 2003. Konsep dan Makna Pembelajaran. Bandung: CV.Alfabeta.

Sudjana. 2005. Metode Statistika. Bandung: Tarsito.

Sudjana, Nana. 2009. Penilaian Hasil Proses Hasil Belajar Mengajar. Bandung: PT. Remaja Rosdakarya.

Trianto. 2011. Model-modelPembelajaran Inovatif Berorientasi Kontruktivistik. Jakarta : Prestasi Pustaka Publisher. 